\title{
BEYOND DOUbling: OVERT EXPLETIVES in European Portuguese Dialects
}

\author{
Ernestina Carrilho, University of Lisbon, Portugal
}

\begin{abstract}
This chapter examines constructions which are tangential to syntactic doubling: overt expletive constructions in non-standard European Portuguese (henceforth EP), with special reference to instances occasionally equated with multiple-subject constructions. It is argued that, given the special status of the EP overt expletive, subject doubling is only illusive in such constructions. More specifically, the syntactic distribution of the EP expletive and the discourse effects displayed in EP expletive constructions substantiate the proposal that, differently from expletive subjects, this expletive is related to a high projection within the left periphery of the sentence, which has special import for the mapping between syntax and illocutionary force in discourse (arguably ForceP).
\end{abstract}

\section{INTRODUCTION}

Given the primordial link between expletives and subjects, the co-occurrence of an overt expletive and an argumental subject suggests a particular case of syntactic doubling, where the sentential subject is the prolific category. In fact, such expletive constructions have often been referred as "double-subject" or, more generally, "multiple-subject constructions" (MSCs). Well-documented in Germanic languages, MSCs have assumed a pivotal role in important advances in the understanding of the structural manifestation of subjects (Chomsky 1995, Bobaljik and Jonas 1996, Boeckx 2001, Vangsnes 2002, a.o.).

EP dialects provide evidence for a construction that could be - and in fact has occasionally been - taken as a case of MSC (see in particular Silva-Villar 1998: 256 and Boeckx 2001: 60). A relevant example is given in (1), where the subject-like expletive ele co-occurs with the argument $e u$, which itself appears to occupy the canonical (preverbal) subject position. 
(1) Ele eu gosto de socorrer as pessoas! $(\mathrm{COV} 23)^{1}$

EXPL I like1SG of helpINF the people

'I like to help people!'

In this chapter, it will be argued, however, that "subject doubling" is illusive in such constructions. In particular, after inspection of the status of the subject-like expletive ele, it will be concluded that this element must be distinguished from ordinary expletive subjects. As a consequence, the apparent case of "subject doubling" must be understood otherwise. The proposal put forth capitalizes on the left peripheral status of the overt expletive in EP dialects, in line with ideas proposed and developed by Uriagereka (1988, 1992, 1995, 2004). Departing from Uriagereka's proposals, however, it is posited that the EP overt expletive lexicalizes the left-peripheral projection of ForceP (cf. Rizzi 1997), in a procedure that appears to be fairly independent from any regular manifestation of the sentential subject (Carrilho 2005). Accordingly, the supposed EP doubling construction turns out to shed light well beyond the subject position, on the span of the sentential structure known as the left periphery - more particularly on its higher portion, which arguably mediates the interface between the syntax of different clause types and the illocutionary force that a sentence adopts in particular communicative conditions.

The organization of the chapter is as follows. First, I will discard the doubling analysis of sentences like (1) above, consolidating the view that, in general, expletive ele differs from expletive subjects, on the basis of: (i) its syntactic distribution (shown in section 2); and (ii) the discourse effects with which it correlates (considered in section 3 ). Then, in section 4, an alternative to the doubling analysis is formulated: the present proposal builds on the left peripheral status of the expletive in the relevant construction, exploiting in particular its connections with the ForceP projection. Finally, section 5 concludes the chapter.

\footnotetext{
I am grateful to two anonymous reviewers and to the editors of this issue for relevant comments and suggestions on a preliminary version of this chapter. In particular, I would like to thank Olaf Koeneman for discussion and many valuable suggestions for improvement. I am also indebted to Ana Maria Martins and Knut Tarald Taraldsen for previous discussions on the material presented here. I take entire responsibility for all remaining errors, misconceptions, and omissions. The research has been partially funded by The Research Council of Norway.

${ }^{1}$ Most data presented here come from the Syntax-Oriented Corpus of Portuguese Dialects, CORDIALSIN (available at http://www.clul.ul.pt/english/sectores/variacao/cordialsin/projecto_cordialsin.php). Given the characterization of this corpus, the examples are drawn from selected excerpts of spontaneous or semi-directed speech produced by non-instructed, old and rural speakers during dialectal interviews for traditional linguistic atlases. Throughout the chapter, CORDIAL-SIN examples are identified by five characters codes (corresponding to the location initials plus the number of the source file, e.g. AAL01). Whenever necessary (and possible), intuitive data are also considered (examples for which no source is indicated).
} 


\section{EXPLETIVe CONSTRUCTIONS ARE NOT MSCS in EP DiALECTS: EVIDENCE FROM THE SYNTACTIC DISTRIBUTION OF EXPLETIVE ELE}

\subsection{Preliminaries}

First of all, a word must be said about EP expletives in general. Note that overt expletives are fairly unexpected elements in a null subject language (henceforth NSL) like EP. In fact, the standard variety of EP appears to conform to the well-established empirical generalization stating the lack of overt expletives in NSLs (Rizzi 1982, 1986, Burzio 1986, Jaeggli and Safir 1989, a.o.). Accordingly, alongside the possibility of dropping out an argumental subject in a finite clause like (2), EP generally displays non-overt non-argumental subjects (see examples in $(3))^{2}$

(2) (O carteiro/ele) tocou a campainha.

the postman/he rang the bell

(3) a. (*Ele) choveu.

EXPL rained

b. (*Ele) está um desconhecido à porta.

EXPL is a stranger at.the door

c. (*Ele) é óbvio que estás cansado.

EXPL is obvious that are2SG tired

Nevertheless, some non-standard EP varieties display an element that looks like an expletive subject, which has often been noticed in impersonal constructions (examples from Mateus et al. 2003: 283 , fn. 5): ${ }^{3}$

(4) a. Ele choveu toda a noite.

EXPL rained all the night

'It (really) rained all night long.'

\footnotetext{
2 I will systematically ignore further distinctions between non-argumental and quasi-argumental subjects, which in fact are irrelevant for the purpose of this chapter. The "non-argumental" label will accordingly apply to both types of expletives (latu sensu).

${ }^{3}$ The cited examples are, in fact, tolerated in near-standard varieties of EP - see section 3.2 below.
} 


\section{Microvariations in Syntactic Doubling}

b. $\quad$ Ele há cada uma!

EXPL has such one

'There are such things!'

c. Tudo está mais caro: ele é o leite, ele é a fruta, ele é o peixe.

everything is more expensive EXPL is the milk EXPL is the fruit EXPL is the fish

'Everything is getting more expensive: milk, fruit, fish...'

In fact, just like expletive subjects in other languages, ele has a pronoun-like shape, actually homophonous with the masculine third person singular subject pronoun (within a system displaying a two-way gender distinction between masculine and feminine). Accordingly, grammarians and dialectologists who notice this non-standard phenomenon most often compare such ele to the sort of obligatory expletive subject that occurs in non-null subject languages like English, and such observations usually appear as sporadic and marginal remarks about impersonal constructions (Leite de Vasconcellos 1901, Dias 1918, Cunha and Cintra 1984, Raposo 1992, Mateus et al. 2003, a.o.). Besides ele, the neuter demonstrative pronouns isto 'this', isso, and aquilo 'that' have equally been taken as expletive subjects in impersonal sentences: ${ }^{4}$

(5) a. Isto é noite. (example from Dias 1918, 1933: 21)

thisEXPL is night

'It's night.'

b. $\quad$ Aquilo há cardos. (AAL75)

thatEXPL has thistles

'There are thistles.'

Under the view that, at least in some EP varieties, ele and the neuter demonstrative pronouns may correspond to expletive subjects, a fairly straightforward move is to compare examples like (6) (and (1) above) to MSCs (cf. Silva-Villar 1998, Boeckx 2001, especially with respect to examples (6a) and (6b)). In fact, the hypothetical expletive subject co-occurs in such examples with an argumental subject which arguably appears in the canonical (preverbal) subject position.

(6) a. Ele aqueles campos estão bem cultivados. (Leite de Vasconcellos 1928: 222)

EXPL those lands are well farmed

\pm 'Indeed, those lands are well farmed.'

\footnotetext{
${ }^{4}$ Although neuter gender is not usually marked in EP, demonstrative pronouns display a three-way gender distinction.
} 
b. Ele os lobos andam com fome. (ibid.)

EXPL the wolves go3PL with hunger

\pm 'Indeed, wolves are hungry.'

c. $\quad$ Aquilo o forno levava ali três ou quatro tabuleiros... (AAL18)

thatEXPL the oven took there three or four trays

\pm 'The oven took about three or four trays.'

In contrast to this view, however, a non-doubling approach to such sentences will be pursued in this chapter, for which I strongly rely on a more general account of expletive constructions in EP dialects. ${ }^{5}$ In particular, I will elaborate on the idea that EP overt expletives substantially differ from expletive subjects and must instead be connected with the left periphery of the sentence (as proposed for Iberian expletives by Uriagereka 1988, 1992, 1995). ${ }^{6}$ The data discussed in section 2.3 below help to consolidate this idea but, concomitantly, motivate the more specific proposal that EP expletives are to be related to ForceP, a high projection in the structure of the left periphery of the sentence.

Before proceeding, some crucial differences between EP expletive constructions in (6) and MSCs will still be pointed out.

\subsection{Some differences with MSCs}

The parallel between the sentences in (6) and MSCs of the German type is in fact only remote. What they have in common is that both of them display an expletive-like element co-occurring

${ }^{5}$ Reasons of space preclude me, however, from dealing here with the whole range of phenomena involved in non-standard EP expletive constructions (and developed in Carrilho 2005). I leave aside, for instance, a different type of construction where expletive ele may also co-occur with an argumental subject, as represented in (i):

(i) Eu tinha ele um irmão que trabalha de carpinteiro também

(PFT17)

I had EXPL a brother who works as carpenter also

\pm 'Even me - I had a brother, who works as a carpenter,...'

In Carrilho 2005, it is argued that such (postverbal) ele must be distinguished from the instances of expletive ele at stake here, so that the expletive in (i) may hardly be mistaken for a subject (see also Haegeman and Van de Velde 2006). Additionally, evidence for this type of expletives is very meager in the corpus considered in Carrilho 2005, which of course calls for additional empirical support (for a universe of about 300 expletive sentences, postverbal ele corresponds to no more than $7 \%$ ).

${ }^{6}$ One of the reviewers points out that at least a traditional source - the Aurélio dictionary - mentions the use of ele besides impersonal constructions, as a kind of pragmatic marker related to some emphasis on the subject. This source has actually been taken as a fairly informal starting point in Carrilho (2005: 6) motivating the inspection of the status of expletive ele well beyond impersonal subjects. As will become clear in section 3, however, the pragmatic role of expletive ele cannot be accurately described as an emphatic effect on the subject. 


\section{Microvariations in Syntactic Doubling}

with a lower argumental subject, which arguably appears in a position outside VP (see Bobaljik and Jonas 1996). Differently from Germanic MSCs, however, EP examples show no restrictions on the type of subject that co-occurs with the expletive, as also mentioned by Boeckx (2002: 60). In fact, regardless of the verb class involved, the argumental subject may well be a non-specific indefinite (as in (7)), a generic DP (as in (8)), a definite description (example (9)) or even an overt pronoun (as in example (1) above):

(7) Ele ninguém me era capaz de abrir a cabeça... (LVR23)

EXPL nobody meDAT was able of openINF the mind

\pm 'In fact, nobody could change my mind.'

(8) Ele a folha do pinheiro é em bico (ALC19)

EXPL the leaf of.the pine-tree is in point

\pm 'Indeed, pine tree leaves are pointed.'

(9) Ele o nosso governo não protege nada a agricultura (COV14)

EXPL the our government NEG protects nothing the agriculture

\pm 'Indeed, our government does not really protect agriculture.'

Expletive ele is also allowed in null subject sentences involving different types of verbs:

(10) Ele voltámos lá todos a ver (COV32)

EXPL went.back1PL there all to seeINF

\pm 'We all went back there to see [that].'

(11) ... esses não morreram. Ele escaparam. (COV32)

those NEG died3PL EXPL escaped3PL

\pm 'Those didn't die. In fact, they escaped.'

(12) ... cheguei, ele lá dormi (COV27)

arrived1SG EXPL there slept1SG

\pm '... I arrived [there], I slept there.'

(13) Ele dão-lhe outro nome (AAL95)

EXPL give3PL-to.it other name [3PL arbitrary subject]

\pm 'Indeed, people give it a different name.'

In sum, the alleged MSC in EP displays no special constraint regarding (i) the type of subject with which the expletive co-occurs (namely, regarding its specificity and grammatical shape); 
and (ii) the type of verb (as illustrated above, not only transitive verbs, but also intransitive and unaccusative verbs).

In addition, it must be noted that, despite the nominative shape, the connection between expletive ele and the subject position is not straightforwardly granted. Nominative case alone does not seem to tell us much about the true status of this element: although this is the case manifested by subjects, it is true that nominative may equally act as a sort of default case for detached elements (just like nominativus pendens in Latin). In the following example, for instance, nominative is the case borne by a topic (first person) pronoun (eu), which is connected with a dative pronoun $(m e)$ inside the comment sentence:

(14) Eu parece-me que isto está certo.

INOM seems-meDAT that this is right

'As for me... it seems to me that this is right.'

\subsection{The peripheral position of expletive ele}

Besides the mentioned differences between MSCs and EP expletive constructions, we may further consider the peripheral position of the EP expletive: in fact, the distribution of expletive ele strongly suggests that this element occurs out of the IP-domain. Below, I will consider a collection of contexts that unequivocally show that expletive ele occupies a position in the left periphery. More precisely, besides occurring before an overt preverbal subject (as illustrated in examples (7)-(9) above), this expletive may equally precede several types of elements that typically appear in the left periphery of the sentence. In examples (15) and (16), for instance, the expletive appears before an adverb in initial position:

(15) Ele agora já ninguém costuma cozer. (OUT32)

EXPL now already nobody uses bake.breadINF

\pm 'Now nobody is in the habit of baking bread anymore.'

(16) Ele aqui nem se diz "nublado". (AAL69)

EXPL here not.even SE says "nublado"

\pm 'We do not even call it "nublado" [=cloudy] here.'

Expletive ele may also occur before different types of topical elements. In example (17), eu 'I' is a sort of hanging topic: this is in fact a left-detached (nominative) form that is only referentially connected with a different category inside the comment sentence (the oblique form mim, which occurs inside a PP): 


\section{Microvariations in Syntactic Doubling}

(17) E ele $[\underline{\mathrm{eu}}]_{\mathrm{i}}$, o homem leu aquilo diante de $[\mathrm{mim}]_{\mathrm{i}}$ ! (COV18)

And EXPL INOM the man read3SG that before of me

\pm 'And, as for me... the man read that before me!'

Example (18) illustrates a different case of topic construction displaying expletive ele: object topicalization. In this example, the expletive precedes the topicalized complement of the existential and impersonal verb haver (etymologically 'to have'):

(18) Ele $[\text { a fome }]_{i}$ não havia $[-]_{i}$ ! (VPA06)

EXPL the hunger not had3SG

\pm 'Hunger didn't exist!'

Remark that in impersonal constructions with the verb haver the argument which usually occurs in postverbal position behaves much like an object - in many EP varieties (including standard EP and the kind of dialectal data inspected here), this argument does not control verb agreement (which typically appears as impersonal third person singular, as in example (19)) and, above all, it appears as an accusative pronoun, as shown in example (20): ${ }^{7}$

\{Havia, *Haviam $\}$ muitos caminhos.

had3SG *had3PL many ways

'There were many ways.'

(20) Havia-os.

had3SG-themACC

Thus, the phrase that follows the expletive in (18) corresponds to a left-peripheral topicalized object, which arguably has moved out from the comment sentence, where it leaves an argumental gap. ${ }^{8}$

Another case where the overt expletive is peripheral to other left-peripheral constituents corresponds to wh-movement contexts, as illustrated by example (21). Here, the expletive precedes a wh-word combined with the focalizing expression é que in a rhetorical question:

(21) Não sendo no Natal, ele quem é que os come?! Ninguém. (OUT50)

NEG beGER in.the Christmas EXPL who is that themACC eat nobody

'If it is not by Christmas, who will eat them?! Nobody.'

\footnotetext{
${ }^{7}$ In some varieties of non-standard EP, agreement may be established between the postverbal argument and the verb. However, this appears to be a rather cultivated urban phenomenon, not unusual in highlyeducated speakers (found in informal, uncontrolled speech situations).

${ }^{8}$ For an exhaustive analysis of topicalization in EP, see Duarte 1987.
} 
Finally, the expletive is also found in contexts involving a dislocated affective phrase (in the sense of Raposo 1995, after Klima 1964) - and, again, expletive ele precedes the left peripheral phrase:

Que ele até com um pau se malha. (MST37)

QUE EXPL even with a stick SE threshes

\pm 'Actually we thresh even with a stick.'

In sum, the evidence presented in this section unequivocally points out the peripheral status of the expletive in EP dialects. It should additionally be noted that such peripheral instances are highly frequent in non-standard EP. For instance, in the corpus inspected in Carrilho 2005, the peripheral occurrences under consideration amount to almost $55 \%$ out of a collection of about 300 expletive sentences.

An approach along the same lines could, in principle, be extended to expletive ele in impersonal constructions in general. What I am suggesting is that even examples such as (4b), here repeated as (23), may correspond to an instance of peripheral ele (as independently proposed by Uriagereka 2004):

Ele [-] há cada uma!

EXPL has such one

'There are such things!'

Such examples may thus compare to expletive constructions involving referential null subjects (see example (24), repeated from (10) above), with the difference that the null subject is nonargumental in examples like (23).

Ele [-] voltámos lá todos a ver (COV32)

EXPL went.back1PL there all to seeINF

\pm 'We all went back there to see [that].'

The overt expletive seems in fact to have the same effect in both kinds of examples (as will become clearer in the next section). Furthermore, there is empirical evidence for the presence of a peripheral expletive in impersonal constructions - remember, for instance, example (18) above. The unified approach here suggested straightforwardly accounts for the peripheral position occupied by the expletive in such examples - which would otherwise be a fairly unexpected position for an expletive subject.

At the end of this section, it must then be acknowledged that the left-peripheral syntactic distribution of expletive ele strongly supports the idea that this element is not a subject in EP. 
As a corollary, no instance of an expletive construction in EP can in fact be equated with a MSC.

\section{EXPLETIVE ELE AND DISCOURSE}

A different piece of evidence for the non-subject status of EP expletive ele is provided by the discourse effects displayed by expletive constructions, which will be considered in the following sections.

\subsection{General connections}

Expletive subjects are frequently identified "by their lack of semantic content" and by "their resolutely grammatical nature" (Svenonius 2002: 5, a.o.). Similarly, expletive ele appears to be devoid of meaning, thus making no contribution to the propositional content of the sentence.

However, it is not true that sentences displaying this expletive strictly correspond to their non-expletive counterparts in the relevant EP varieties. This is evident when we consider the impersonal expletive constructions that are tolerated in (near-)standard EP (illustrated in examples (4) and (23) above). In this case, the use of expletive ele by educated speakers generally corresponds to a more expressive way of saying things, allowed both in spoken and in written (even literary) EP, and most often connected with exclamative or emphatic sentences. ${ }^{9}$ The expletive has the effect of strengthening the expressive value of such sentences, an effect that can be extended, in other EP varieties, to other expletive constructions (besides impersonal constructions and expressive sentences).

In a sense, thus, the overt expletive does not correspond to a mere grammatical device optionally displayed by some EP varieties. On the contrary, whenever present, expletive ele makes a contribution to the sentence, operating on the non-propositional part of its meaning. As such, this EP expletive rather relates to the interface syntax-discourse and, to a certain extent, it may be equated with a sort of pragmatic marker (in the sense of Fraser 1996), whose effects will be elucidated in the next section.

Before proceeding, however, we may still invoke a different connection: the case of a different expletive related to discourse conditions rather than to a visibility requirement on the subject position. This is arguably the case of the expletive sitä in Finnish, a topic-prominent NSL. Holmberg and Nikanne (2002) relate the presence of the overt expletive in Finnish to a

\footnotetext{
${ }^{9}$ However, for these speakers, the expletive does not seem to be a productive means allowed in any type of impersonal construction - the presence of expletive ele is essentially limited to sentences involving existential haver and presentative ser 'to be', thus suggesting that, in standard EP, the expletive is lexically restricted to some fixed expressions.
} 
(quasi-)generalized requirement for the topic position to be visible - whenever no argument in a sentence qualifies as presupposed (thus carrying a [-Foc] feature), merging of the overt expletive saves the derivation and fulfills the requirement for a Spec in the presupposition domain to be filled up. Accordingly, "sitä is not an expletive subject but an expletive topic" (Holmberg and Nikanne 2002: 96).

Nevertheless, the discourse effects displayed by EP expletive ele significantly differ from the discourse import of the Finnish expletive. In fact, a sharp contrast arises if we try to extend Holmberg and Nikanne's proposal to the sort of EP data presented in the previous sections of this chapter. Consider, for instance, example (25) below:

Ele o tear do pardo era muito largo. (OUT21)

EXPL the loom of.the dun [cloth] was very wide \pm 'Indeed, the loom for dun cloth was very wide.'

The expletive co-occurs here with a preverbal subject, just like in some of the examples considered above. In the non-expletive counterpart of this sentence (i.e., o tear do pardo era muito largo), the preverbal subject normally corresponds to a (non-marked) topic reading in EP (Duarte 1987, Martins 1994, Costa 1998). In other words, the phrase o tear do pardo establishes the entity for which the comment era muito largo is relevant, in a categorical judgment (Kuroda 1972) corresponding to the topic-comment articulation. At first glance, one might speculate that the expletive plays a sort of detopicalizing effect on the preverbal subject. That is, just like the Finnish expletive, ele would become itself a kind of topic, while the remaining sequence would correspond to a sort of thetic judgment. This is not however the case: the context where the mentioned example occurs provides evidence for discarding such a speculation. In fact, the expletive construction answers the following question: Mas o tear era igual ou era mais largo? 'But did the loom have the same width or was it wider?' In the answer, the expletive does not seem to affect the regular distribution of information: $o$ tear do pardo has a topic reading (mentioned as o tear 'the loom' in the question - in a wider context, the loom is the topic of the conversation at that moment of the interview); era muito largo actually acts as the piece of new information which answers the question. Thus, the analysis proposed by Holmberg and Nikanne (2002) cannot be extended to the EP expletive facts: in an example like (25), there is actually a part of the sentence which is [+focus] (namely, era muito largo) and, accordingly, there is already some [-focus] element (o tear do pardo). Consequently, there would be no need for the EP expletive, if this element was to be related to the sort of [-focus] checking relevant in Finnish expletive constructions.

Furthermore, it can be remembered (from section 2.3 above) that expletive ele may co-occur with topics - namely with marked topics different from the subject of the sentence, as in examples (17) and (18) above. 


\section{Microvariations in Syntactic Doubling}

Hence, although the EP overt expletive displays a general connection with the syntax-discourse interface, it must be acknowledged that its discourse effects are not connected with information distribution patterns (to which the notions topic and focus pertain).

\subsection{Particular effects}

How is then expletive ele related to the discourse level? From the inspected data, a common discourse effect seems to emerge: the different occurrences of ele (in impersonal constructions and beyond) generally correlate with some emphatic (though slightly fuzzy) value in both quasi-standard and dialectal examples. In order to help determine the nature of such a vague effect, let us now consider some additional examples.

As already mentioned, expletive ele seems to have the effect of emphasizing the expressive value displayed by some sentences. This is the case for exclamative sentences, for which even the standard variety uses the expletive as a more expressive means, albeit restricted to some impersonal constructions (see example (23) above). In other EP dialects, this emphasizing effect extends to other types of constructions (see also example (1)):

(26) Ele ele disse que era (...) de São João da Madeira, homem! (COV21)

EXPL he said that was from São João da Madeira manINTJ

'Actually, he said that he was from São João da Madeira, man!'

(27) Ele nunca me olhava a nada, nunca tinha medo nenhum! (ALV25)

EXPL never me regarded1SG to nothing never had1SG fear none

\pm 'I avoided nothing, I was never afraid of anything!'

As a general observation, it can be pointed out that in this type of sentence the role of the expletive is always that of adding some emphasis to the exclamative's expressive value.

A similar effect may also be found in other sentence types. In examples involving imperative sentences, such as (28), expletive ele again seems to relate to some emphasis on a specific pragmatic value of the sentence: in this case, it is the directive force of the imperative that ends up being amplified.

- Quer passar por lá para ver?

'- Do you want to go there to see it?'

- Ele vamos embora! (FIG27)

EXPL goPRES.SBJ.1PL away

\pm 'Let's go [right now]!' 
Although such imperative examples are not frequent in the inspected corpus, this observation can be further developed by some intuitive data, which provide the following contrast: while expletive ele may well co-occur with other words that strengthen the directive value of the imperative (like já 'right now', mesmo 'really', in example (29)), the result is fairly awkward when we try to combine the expletive with an expression that mitigates the directive force (as in example (30)):

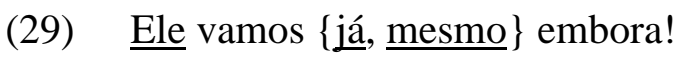

$$
\text { \#Ele vamos embora, }\left\{\frac{\{\text { se não se importam, }}{\text { if you don't mind }} \frac{\text { por favor }}{\text { please }}\right. \text { ! }
$$

Thus, the discourse effect obtained by the expletive appears to be analogous to that found in exclamatives: ele reinforces a specific pragmatic value of the sentence (expressive in exclamatives, directive in imperatives). It remains now to be seen whether a related effect may be found in declarative sentences and in questions.

Let us first turn to declaratives. In sections 2.2 and 2.3 above, several declarative examples were presented. In all those examples, the expletive may in fact correlate with some emphatic effect on the assertive value of such declarative sentences. Remember, for instance, example (9), here repeated as (31), for ease of reference:

Ele o nosso governo não protege nada a agricultura (COV14)

EXPL the our government NEG protects nothing the agriculture

Such an example could easily be paraphrased with a sentence involving some sort of assertive emphatic expression, such as de facto 'in fact', realmente 'indeed', é verdade que... 'it is true that'.

\section{$\{\underline{\text { De facto }}, \underline{\text { realmente, }}, \underline{\text { é verdade que }}\}$ o nosso governo não protege nada a agricultura}

In other words, the main effect of the overt expletive corresponds, in such declarative cases, to a general emphasis on the assertive value of the utterance. To the extent that such emphasis indicates how much the speaker stands for the truth of the statement that he is making, the expletive can thus be equated, in such declarative sentences, with a sort of (strong) evidentiality marker, as suggested in Uriagereka 2004.

Remark, in this respect, that, intuitively, the expletive is not felicitous in declarative sentences that adopt pragmatic values other than assertion, as in example (33) (if uttered as a polite request): 


\section{Microvariations in Syntactic Doubling}

${ }^{\#}$ Ele $(\mathrm{eu})$ queria um café.

EXPL INOM wantIMPERF a coffee

'I would like (to have) a coffee'

If we now turn to interrogative sentences, an important difference must be acknowledged. In questions, expletive ele does not seem to display the effect found in other sentence types, namely that of emphasizing a usual pragmatic value (assertive in declarative sentences, directive in imperatives, expressive in exclamatives). In fact, expletive ele cannot occur in genuine information questions. Contrary to expectation, thus, the expletive cannot turn an interrogative into an emphatic request for information. The interesting question why this should be so is left open here.

A related effect of the expletive in questions is, however, worth mentioning. Remember example (21) above, here repeated as (34):

(34) Não sendo no Natal, ele quem é que os come?! Ninguém. (OUT50)

NEG beGER in.the Christmas EXPL who is that them eat nobody

'If it is not by Christmas, who will eat them?! Nobody.'

This is an instance of a rhetorical question, which arguably shares with exclamatives some expressive pragmatic value (see Benincà 1995: 129 and Mateus et al. 2003: 481). The relevant point is that interrogative sentences displaying the expletive ele always involve an expressive reading and cease to be interpreted as pure requests for information: besides rhetorical questions, other "special interrogatives" (in the sense of Obenauer 2006) can be obtained, just like "surprise-disapproval questions", and "Can't-find-the-value-of-x questions" (Obenauer 2004, 2006).

This seems similar to the effect displayed by "aggressively non-D-linked" $w h$-phrases (Pesetsky 1987), like que raio/que diabo 'what lightning/what devil' in EP. Although this type of wh-phrase allows for both (i) a genuine information request interpretation, and (ii) a rhetorical question interpretation (both of them illustrated in example (29)), the fact is that such wh-phrases also signal the involvement of the speaker in such a way that they become totally inadequate in neutral questions formulated in formal situations (e.g. an exam).

- Que raio de gente come estes bolos?

what "the hell" people eat these cakes

'Who the hell eats these cakes?'

A: - As crianças.

the children

'Children do.' 
B: - Ninguém.

nobody

Similarly, the overt expletive may not occur in such neutral interrogatives. Instead, ele seems to always correlate with some involvement of the speaker, which is characteristic of expressive questions. Accordingly, the expletive may perfectly co-occur with a "wh-the-hell"-phrase in such interrogatives:

(30) - Ele que raio de gente come estes bolos?

We may thus acknowledge that the effect of expletive ele in interrogative sentences sounds already familiar: an effect connected with the illocutionary force of a sentence, that of emphasizing a particular pragmatic value. In this case, however, this effect is limited to the expressive value that can be found in special questions.

Summarizing thus far, then, we have seen in this section that: (i) EP expletive sentences differ from their non-expletive counterparts; (ii) just like expletive subjects, expletive ele does not contribute to the propositional part of sentence meaning; (iii) the contribution of this overt expletive is to be related to the syntax-discourse interface; (iv) the relevant discourse effect operates at the level of the illocutionary force assumed by sentences in use. More precisely, expletive ele is connected with a particular pragmatic value assumed by each sentence type: its presence correlates with an emphatic effect on the (i) expressive, (ii) command or (iii) assertive values, respectively assumed by (i) exclamatives and special questions, (ii) imperatives and (iii) declarative sentences.

\section{EXPLETIVE ELE AND FORCEP}

Such connections with discourse straightforwardly fall into place with the expletive's distributional behavior in the left periphery of the sentence (seen in section 2), a space where discourse notions often appear codified. Accordingly, the proposal put forth in this section states that the overt expletive in EP occupies a structural position in the left periphery which is relevant to the sort of discourse effect displayed in EP expletive constructions. Such a proposal gives additional substance to the idea that overt expletives in a NSL such as EP are special (i.e., different from subject expletives) and must be related to the space above IP (Uriagereka 1992, 1995).

If we recall now the interplay between expletive ele and other left peripheral elements in EP (see section 2.3), the general observation that arises is that the expletive occupies a high 


\section{Microvariations in Syntactic Doubling}

position when it occurs in a fairly "crowded" left periphery. In fact, the expletive may actually precede different types of marked topics, dislocated affective phrases and dislocated wh-phrases, for instance. That such elements are peripheral in the sentence structure is a fairly uncontroversial matter.

In some examples, the peripheral positions involved are arguably located in the high space of the left periphery. Consider, for instance, the sort of topic constructions illustrated in (37) (repeated from (17) above):

(37) E ele $[\underline{\mathrm{eu}}]_{\mathrm{i}}$, o homem leu aquilo diante de $[\mathrm{mim}]_{\mathrm{i}}$ ! (COV18)

And EXPL INOM the man read3SG that before of me

\pm 'And, as for me... the man read that before me!'

Here, the topic eu and the element to which it is linked inside the comment (de mim) are only loosely connected: both of them are first singular person pronouns, but there is no additional syntactic connection between them (they are in fact differently marked for case). In this respect, this example is very similar to hanging topic constructions. Arguably, hanging topics occupy a high position in the left periphery, higher than other types of marked topics (Benincà and Poletto 2001, a.o.).

Another case to consider is that of rhetorical questions. In such sentences, the expletive precedes the $w h$-phrase (remember example (21) above), which again implies that ele occupies a high peripheral position. To the extent that special questions may be argued to activate a portion of the left periphery higher than that activated by standard questions (see in particular Obenauer 2006), EP expletive ele again appears straightforwardly connected with such a high portion of the sentential structure.

Since negative evidence cannot be found in the inspected corpus, we may at this point appeal to some intuitive data, which in fact appear to confirm the idea that expletive ele must be related to the leftmost position in the left periphery. Indeed, a sentence in which the expletive occurs below the hanging topic seen above sounds fairly weird:

${ }^{\#}[\underline{\mathrm{Eu}}]_{\mathrm{i}}, \underline{\text { ele }}$ o homem leu aquilo diante de $\left[\mathrm{mim}_{\mathrm{i}}\right]$ !

A related issue to consider is the distribution of expletive ele in embedded contexts. In fact, if the EP expletive is to be connected with a high position in the left periphery, we would expect at least some restrictions on its distribution in embedded clauses. If we take into consideration the inspected data from CORDIAL-SIN, we must acknowledge that, although most examples occur in independent or matrix contexts, the expletive also appears in some embedded contexts, as in the example given below, which involves a that-clause: 
(39) Tu sabes bem que ele em Paçô eles viram para aquele lado (COV28) you know well that EXPL in Paçô they turn to that side 'You know well that, at Paçô, they turn to that side.'

It seems fairly natural to find the overt expletive in such an embedded context, which is dependent on an assertive predicate (cf. Torrego and Uriagereka 1993). Since the matrix predicate implies the existence of a claim to truth (i.e. an assertion) in its finite complement, the expletive can play in this kind of environment the expected discourse effect on the embedded assertion. In such embedded clauses, the expletive appears below the complementizer (que in the example), even if it precedes some peripheral phrase (like the preposed PP em Paçô in example (39)).

By contrast, and in conformity with our expectation, the expletive does not seem to be felicitous in finite clauses embedded under verbs of questioning - remember that, in matrix contexts, expletive ele only appears in special questions:

a. Perguntaram-me ( ${ }^{*}$ ele) quem ( ${ }^{*}$ ele) me convidou. asked3PL-to.me EXPL who EXPL me invited3SG

'They asked me who invited me.'

b. Perguntaram-me se (" ${ }^{\text {ele }}$ ) eu tinha sido convidado. asked3PL-to.me whether EXPL I had been invited 'They asked me whether I had been invited.'

The embedded contexts that allow the EP expletive are not limited to assertive that-clauses, however: they also include some adverbial clauses, such as if- and when-clauses, and even purpose inflected infinitive clauses. In other words, contrary to expectation, the distribution of expletive ele is not in fact strictly restricted in embedded contexts and may involve clauses that are taken to involve a more contained C-domain.

In view of all this, it remains to be determined how high the EP expletive appears within the structure of the left periphery. First, let us briefly consider the nature of the left peripheral space in connection with the discourse notions involved in EP expletive constructions.

As is well-known, the C-domain above IP has been decomposed into several functionally specialized projections, thus mediating a privileged codification of particular discourse properties (Rizzi 1997, Ambar 1997, 1999, Benincà and Poletto 2001, a.o.). Under Rizzi's initial proposal, these projections consist of two basic systems: (i) one which provides the upper and lower bounds for the C-domain, encoding the relationships between CP and the higher structure or the articulation of discourse, on the one hand, and the relationship between $\mathrm{CP}$ and the "inside", i.e. the IP embedded under it, on the other; (ii) a second system relating to the informational articulation of topic-comment and of focus-presupposition. The crucial 


\section{Microvariations in Syntactic Doubling}

heads to the former system are Force and Finiteness, encoding respectively the specification of force (often also the clausal type) of a sentence and the relationship to certain properties of the verbal system of the clause. Such Force-Finiteness system is taken as the essential (and ubiquitous) part of the C-domain, while the second system, including the Topic and Focus heads, is assumed to be present in a structure only if needed. When activated, such TopicFocus system appears "sandwiched" in between Force and Finiteness. Subsequently, several extensions of this proposal have further expanded different fields within the C-domain, leading to a collection of projections which may appear subsumed under the "topic field" and the "focus field" (Benincà and Poletto 2001), and under what one might call the "force field" (e.g. the elaboration on the force of interrogatives in Poletto and Pollock 2000, Obenauer 2004; or the expansion of ForceP on the basis of the internal structure of adverbial clauses in Haegeman 2002). Thus, a fairly inflated structure of the left periphery has come to closely encode specific pragmatic features, resulting in an extremely detailed mapping between syntax and discourse. Besides focus/presupposition and topic/comment articulations, other pragmatic notions have gained a space within the left periphery, such as several aspects relating to speech act systems, like those involved in different types of questions (Obenauer 2004).

It seems thus fairly intuitive to find a place for expletive ele in such a left periphery. Remember that the main discourse effects of the presence of the overt expletive relate to aspects having to do with the illocutionary force of sentences (namely, the emphasis on particular pragmatic values expressed by exclamatives and some interrogatives, imperatives and declaratives in specific speech acts). Since the structure of the left periphery includes a space dedicated to the codification of aspects related to the force of a sentence (ForceP in Rizzi 1997 and subsequent works), it seems natural to find a place for the EP expletive there.

The main problem for such an approach seems to be the fairly permissive distribution of the expletive in embedded contexts. First, as noted above, the expletive must follow, in such contexts, the complementizer. If this element is taken to appear as a Force head, then there seems to be no additional room for the expletive inside the projection of Force. Second, it is not evident that all the cases of embedded clauses that allow the overt expletive must include a Force projection. Although these issues cannot be extensively developed here, I would like to suggest a possible way to circumvent this problem. First, the order complementizer-expletive would straightforwardly follow if one adopts a further expansion of Force into two different heads (and respective projections), along the lines of Haegeman (2002: 162). Thus, subordinate clauses would count with a head (Sub) that serves to subordinate the clause and another head that encodes force, as also proposed in Bhatt and Yoon 1992, a. o.. Second, concerning the structure of the left periphery in different types of embedded clauses, it must be acknowledged that this is to a great extent an issue still open to debate (cf. Heycock 2006) and that the presence of the expletive could be seen as one among several unexpected root phenomena that may occur in such contexts. This is however a matter that I will not pursue here. 
Thus, it may be conceived that in EP expletive constructions the overt expletive appears in the spec position of the high peripheral projection ForceP, as represented in (41).

$$
\begin{gathered}
\text { [FoRCEP [EXPLEle] [FORCE } \left.\left.{ }^{0}[\text { IP O nosso governo não protege nada a agricultura }]\right]\right] \text {. } \\
\text { EXPL the our government NEG protects nothing the agriculture }
\end{gathered}
$$

In structural terms, such an analysis would correctly predict the sort of interactions that the expletive displays in the left periphery: namely, it would accurately account for the fact that expletive ele appears as the leftmost peripheral element when combined with other peripheral material, such as topics, dislocated wh-phrases or dislocated affective phrases (see section 2.3). Additionally, the speaker involvement that EP expletive constructions convey could also be straightforwardly related to such a space, strengthening Haegeman's idea that: ${ }^{10}$

[...] the presence of the functional head Force [...] directly correlate[s] with what is referred to as 'illocutionary force', the fact that the speaker takes on the proposition as part of a speech act (assertion, prediction, question, etc.).

To be licensed, Force, being about speaker commitment, must be anchored to a speaker or a potential speaker. (Haegeman 2002: 159)

Such a proposal for EP expletive constructions inevitably interacts with issues concerning the syntactic representation of clause types. In this respect, remark, first, that this proposal is not necessarily incompatible with the view that the sentential force (the one relevant for clause typing, following Chierchia and McConnell-Ginet 1990) must be distinguished from the illocutionary force obtained with the intentional use of a sentence as a speech act (Searle 1965). While remaining agnostic as to the question whether (or how) different clause types or sentential forces are differently codified in the syntactic structure, the present proposal could in fact be compatible with different understandings of ForceP. The analysis here suggested specifically concerns emphatic sentences involving the use of the expletive ele. It is for such constructions that it is proposed that a projection headed by Force is involved and that the EP expletive occupies its Spec position, thus behaving fairly differently from an expletive subject. In this sense, in line with Haegeman's terms above, ForceP is to be related to the illocutionary force, which may in fact be independent from the codification (or manifestation) of different sentential forces (see example (36), for instance). In exclamative, interrogative, imperative or declarative sentences, the expletive would involve the same sort of visibility for the ForceP projection, without affecting the internal structure of the remaining sentence. This, in principle, appears to be compatible either with the view that different clause types result from different

\footnotetext{
${ }^{10}$ A natural extension of this idea would be to endow the EP expletive with some formal feature related to speaker involvement, which must be checked in spec ForceP. Limitations of space preclude me from motivating and developing such a proposal here.
} 


\section{Microvariations in Syntactic Doubling}

grammatical configurations or with the idea that particular sentential types are codified by a particular grammatical feature, which could also be related to ForceP. Similarly, the articulation with the view that clause typing arises from the pairing of syntactic configurations and their semantic properties (as developed in Zanuttini and Portner 2003) could also be explored. ${ }^{11}$

The EP expletive, here related to [spec, ForceP], does not change an independently obtained illocutionary force (even special questions are possible without the presence of the expletive). However, not every illocutionary value allowed for a particular clause type (given the appropriate discourse conditions) can be maintained in EP expletive constructions. For instance, declarative sentences including an expletive may not assume a command value, while their non expletive counterparts may (just like in the case of English I want you to do this job today). Instead, expletive declarative sentences always appear as emphatic assertions. Similarly, imperatives displaying the expletive ele appear as emphatic commands (but not as polite requests). In the case of interrogatives, the presence of the expletive strictly correlates with expressive readings (thus limited to special questions), with the result that no expletive question can be interpreted as a standard and mere information request.

The proposal here sketched for the EP expletive could, in principle, be extended to overt expletives in other Romance NSLs, such as Galician (Álvarez 1981, 2001, Uriagereka 1995), some varieties of American Spanish (Henríquez Ureña 1939, Fernández Soriano 1999) and some varieties of Catalan (Spitzer 1945, Solà et al. 2002). In all such languages, overt expletives also seem to be connected with some emphasis on specific illocutionary values. For instance, in Galician, which is very close to EP, expletive el largely conforms to the EP pattern, thus depending on illocutionary values relating to expressivity in exclamative (see example (42)) and interrogative clause types (again, the expletive appears to be confined to special questions), but also (strong) assertion in declarative clause type (see Álvarez 2001).

El tamém son ben caras! [as sardiñas]

EXPL even are very expensive the sardines

'They [the sardines] are very expensive!'

Likewise, a looser connection could in principle be established with the expletive ell in some Balear Catalan varieties, which is currently understood as an "exclamatory particle" (Solà et al. 2002).

\footnotetext{
Ell aixó no acaba mai!

EXPL this NEG ends up never

'This does not end up!'
}

\footnotetext{
${ }^{11}$ Interesting as they are, such issues would go far beyond the purpose (and space) of this chapter, so that I leave them aside for now.
} 
In this case, such an expletive would only correlate with the expressive value of ForceP.

\section{CONCLUSION}

In this chapter I have considered a supposed case of subject doubling from the angle of expletive constructions in EP dialects. It has been argued that the overt expletive appearing in such constructions must be distinguished from a regular expletive subject. On the basis of the syntactic distribution of this expletive and the discourse effects thus displayed, it has been proposed that expletive ele lexicalizes the ForceP projection in the $\mathrm{C}$-domain, which is assumed to mediate the mapping between the sentential force and the illocutionary force that a sentence may have as a speech act. As a consequence, the alleged subject doubling in such expletive constructions vanishes into a discourse relevant device, independent from the structural manifestation of subjects, but providing new clues about the fine structure of the left periphery of the sentence and thus widening the limits within which the interface discourse-syntax must be discussed.

\section{REFERENCES}

Álvarez, R. (1981). O Pronome Persoal en Galego. Doctoral dissertation, Universidade Santiago de Compostela.

Álvarez, R. (2001). El Vai Ben Así: Pervivencia e Construccións de el Invariable. Cadernos de Lingua, 23, 5-33.

Ambar, M. (1997). Towards a definition of CP - Evidence from TopicFocusP and EvaluativeP. Talk presented at Going Romance. Groningen, December 1997.

Ambar, M. (1999). Aspects of the Syntax of Focus in Portuguese. In: The Grammar of Focus

(G. Rebuschi and L. Tuller, eds.), pp. 23-53. John Benjamins, Amsterdam / Philadelphia.

Aurélio Ferreira, A. B. de H. (1986) Novo Dicionário Aurélio. Nova Fronteira, Rio de Janeiro. (2nd ed., rev.)

Benincà, P. (1995). Il Tipo Esclamativo. In: Grande Grammatica Italiana di Consultazione (L. Renzi, G. Salvi and A. Cardinaletti, orgs.), Vol. 3, pp. 127-152. Il Mulino, Bologna.

Benincà, P. and C. Poletto (2001). Topic, Focus and V2: Defining the CP Sublayers. Ms. University of Padova.

Bhatt, R. and J. Yoon (1992). On the Composition of Comp and Parameters of V-2. WCCFL, 10, 41-52.

Bobaljik, J. D. and D. Jonas (1996). Subject Positions and the Roles of TP. LI, 27, 195-236. 
Boeckx, C. (2001). On the co-occurrence of expletives and definite subjects in Germanic. In: Issues in Formal German(ic) Typology (W. Abraham and C. J.-W. Zwart, eds.), pp. 45-63. John Benjamins, Amsterdam / Philadelphia.

Burzio, L. (1986). Italian Syntax. A Government-Binding Approach. Kluwer, Dordrecht.

Carrilho, E. (2005). Expletive ele in European Portuguese Dialects. Doctoral dissertation, Universidade de Lisboa. (http://www.clul.ul.pt/equipa/ecarrilho/Carrilho2005.pdf)

Chierchia, G. and S. McConnell-Ginet (1990). Meaning and Grammar: An Introduction to Semantics. MIT Press, Cambridge.

Chomsky, N. (1995). The Minimalist Program. MIT Press, Cambridge.

Costa, J. (1998). Word Order and Constraint Interaction: A Constraint-Based Approach. Doctoral dissertation, HIL Leiden University.

Cunha, C. and L. F. Lindley Cintra (1984). Nova Gramática do Português Contemporâneo. Ed. João Sá da Costa, Lisboa.

Dias, A. E. da S. (1918). Syntaxe Histórica Portuguesa. Livraria Clássica Editora, Lisboa. 2nd edition, 1933.

Duarte, I. (1987). A Construção de Topicalização na Gramática do Português: Regência, Ligação e Condições sobre Movimento. Doctoral dissertation, Universidade de Lisboa.

Fernández Soriano, O. (1999). El Pronombre Personal. Formas y Distribuciones. Pronombres Átonos y Tónicos. In: Gramática Descriptiva de la Lengua Española (I. Bosque and V. Demonte, coords.), Vol. 1, pp. 1209-1273. Espasa, Madrid.

Fraser, B. (1996). Pragmatic Markers. Pragmatics, 6, 167-190.

Haegeman, L. (2002). Anchoring to Speaker, Adverbial Clauses and the Structure of CP. Georgetown University Working Papers in Theoretical Linguistics (S. Mauck and J. Mittelstaedt, eds.), 2, 117-180.

Haegeman, L. and D. Van de Velde (2006). Pleonastic tet in the Lapscheure dialect. Workshop on Doubling, Meertens Institute, March 2006. Electronic publication: http://www.meertens.nl/projecten/edisyn/Online_proceedings/Paper_Haegeman-

VandeVelde.pdf.

Henríquez Ureña, P. (1939). Ello. Revista de Filología Hispánica, 1, 209-229.

Heycock, C. (2006). Embedded Root Phenomena. In: The Blackwell Companion to Syntax (M.

Everaert and H. van Riemsdijk, eds.). Vol. 2, pp. 174-209. Blackwell, Malden, Mass.

Holmberg, A. and U. Nikanne (2002). Expletives, Subjects, and Topics in Finnish. In: Subjects, Expletives, and the EPP (P. Svenonius, ed.), pp. 71-105. Oxford University Press, Oxford. Jaeggli, O. and K. Safir, eds. (1989). The Null Subject Parameter. Kluwer, Dordrecht.

Klima, E. (1964). Negation in English. In: The Structure of Language: Readings in the Philosophy of Language (J. Fodor and J. Katz, eds.), pp. 246-323. Prentice-Hall, Englewood Cliffs, New Jersey.

Kuroda, S.-Y. (1972). The Categorical and the Thetic Judgment. Evidence from Japanese Syntax. Foundations of Language, 9, 153-185. 
Leite de Vasconcellos, J. (1901). Esquisse d'une Dialectologie Portugaise. Centro de Linguística da Universidade de Lisboa/Instituto Nacional de Investigação Científica, Lisboa. 3rd edition, 1987.

Leite de Vasconcellos, J. (1928). Opúsculos. Universidade de Coimbra, Coimbra.

Martins, A. M. (1994). Clíticos na História do Português. Doctoral dissertation, Universidade de Lisboa.

Mateus, M. H. M., A. M. Brito, I. Duarte, I. H. Faria and S. Frota, G. Matos, F. Oliveira, M. Vigário and A. Villalva (2003). Gramática da Língua Portuguesa. Caminho, Lisboa.

Obenauer, H.-G. (2004). Nonstandard wh-questions and alternative checkers in Pagotto. In: Syntax and Semantics of the Left Periphery, Interface Explorations 9 (H. Lohnstein and S. Trissler, eds.), pp. 343-384. Mouton de Gruyter, Berlin and New York.

Obenauer, H.-G. (2006). Special Interrogatives - left periphery, wh-doubling, and (apparently) optional elements. In: Romance Languages and Linguistic Theory 2004. Selected papers from 'Going Romance', Leiden, 9-11 December 2004 (J. Doetjes and P. González, eds.), pp. 247-273. John Benjamins, Amsterdam.

Pesetsky, D. (1987). Wh-in-situ: Movement and Unselective Binding. In: The Representation of (In)definiteness (E. Reuland and A. G. B. ter Meulen, eds.), pp. 98-130. MIT Press, Cambridge.

Poletto, C. and J.-Y. Pollock (2000). On the Left Periphery of Some Wh-Questions. Ms. Università di Padova and Université de Picardie à Amiens. [Published in: L. Rizzi, ed. (2004). The Structure of CP and IP. The Cartography of Syntactic Structures, Vol. 2, pp. 251-296. Oxford University Press, Oxford.]

Raposo, E. P. (1992) Teoria da Gramática. A Faculdade da Linguagem. Caminho, Lisboa.

Raposo, E. P. (1995). Próclise, Ênclise e a Posição do Verbo em Português Europeu. In: $O$ Amor das Letras e das Gentes. In Honor of Maria de Lourdes Belchior Pontes, (J. C. dos Santos and F. G. Williams, eds.), pp. 455-481. Center for Portuguese Studies, University of California at Santa Barbara, Santa Barbara.

Rizzi, L. (1982). Issues in Italian Syntax. Foris, Dordrecht.

Rizzi, L. (1986). Null Objects in Italian and the Theory of pro. LI, 17, 501-557.

Rizzi, L. (1997). The Fine Structure of the Left Periphery. In: Elements of Grammar. Handbook in Generative Syntax (L. Haegeman, ed.), pp. 281-337. Kluwer, Dordrecht.

Searle, J. (1965). What is a speech act? In: Philosophy in America (Max Black, ed.), pp. 221-239. Cornell University Press, Ithaca.

Silva-Villar, L. (1998). Subject Positions and the Roles of CP. In: Romance Linguistics. Theoretical Perspectives (A. Schwegler, B. Tranel and M. Uribe-Etxebarria, eds.), pp. 247-270. John Benjamins, Amsterdam / Philadelphia.

Solà, J., M.-R. Lloret, J. Mascarò and M. Pérez Saldanya, dir. (2002). Gramática del Català Contemporani. Empúries, Barcelona. 
Spitzer, L. (1941). Paralelos Catalanes y Portugueses de ello. Revista de Filología Hispánica, 3, 272.

Svenonius, P. (2002). Introduction. In: Subjects, Expletives, and the EPP (P. Svenonius, ed.), pp. 3-27. Oxford University Press, Oxford.

Torrego, E. and J. Uriagereka (1992). Indicative Dependents. Ms. University of Massachusetts at Boston and University of Maryland at College Park.

Uriagereka, J. (1988). On Government. Doctoral dissertation, University of Connecticut.

Uriagereka, J. (1992). A Focus Position in Western Romance. Talk presented at GLOW 15. Lisbon, 1992.

Uriagereka, J. (1995). An F Position in Western Romance. In: Discourse Configurational Languages (K. É. Kiss, ed.), pp. 153-175. Oxford University Press, Oxford.

Uriagereka, J. (2004). A Peripheral Pleonastic in Western Iberian. Hand-out of talk presented at Expletive Subjects in Romance and Germanic Languages. Konstanz, Germany, November 2004.

Vangsnes, Ø. (2002). Icelandic Expletive Constructions and the Distribution of Subject Types. In: Subjects, Expletives, and the EPP (P. Svenonius, ed.), pp. 43-30. Oxford University Press, Oxford.

Zanuttini, R. and P. Portner (2003). Exclamative Clauses: at the Syntax-Semantics Interface. Language, 79, 39-81. 